\title{
The Proxymate Analysis and Carbohydrate Compound of Rice Analogue Tuber Base as Energy Sources Alternative for Metabolic Syndrome
}

\author{
Yunita Rakhmawati ${ }^{1, *}$ Abdul Gofur ${ }^{2}$, Rahmi Masita $^{3}$, Narisa Ika Kusumadewi ${ }^{4},{ }^{2}$ a \\ Nanda Febriana ${ }^{5}$ \\ 1-5 Department of Biology, Faculty of Mathematics and Natural Sciences, Universitas Negeri Malang, Malang, East \\ Java, Indonesia \\ *Corresponding author. Email: yunita.rakhmawati.fmipa@um.ac.id
}

\begin{abstract}
Adults with metabolic syndrome have a higher risk of mortality than people without metbolic syndrome. To minimize the risk of metabolic syndrome it is necessary to improve a healthy lifestyle and be selective towards food. The source of carbohydrates is not only from morning rice, but also type of tubers such as suweg and ganyong, the yam can be processed into a product that is able to maintain food security in Indonesia called analog rice. This study proposed to knowing the proxymate and carbohydrate compound of rice analog tuber base. The results of this study are the energy almost are as many ganyong as suweg. In addition, the content of protein, fat, and carbohydrate is suweg larger than ganyong. Furthermore, the starch and total sugar are fewer in ganyong than suweg. The other carbohydrate compound is amylose, and reduced sugar is bigger ganyong than suweg.
\end{abstract}

Keywords: proxymate analysis, carbohydrate compound, rice analogue, metabolic syndrome

\section{INTRODUCTION}

Metabolic syndrome (SM) is a group of metabolic disorders resulting from a combination of abnormal fasting glucose, increased waist circumference or obesity centers, lipids that experience abnormalities in the presence of increased triglycerides (TAG) or low highdensity lipoprotein (HDL-C) cholesterol levels, as well as blood pressure [1]. Based on the epidemiological data of prevalence of metabolic syndrome (SM) in the world is $20-25 \%$ [2]. According to the Framingham Offspring Study, the results were $23.1 \%$ in women and $29.4 \%$ in vulnerable men aged 26-82 years. Adults with metabolic syndrome (SM) have a higher risk of mortality than people without metbolic syndrome (SM). In addition to the risk of death, the development of type 2 diabetes is five times greater experienced by people with metabolic syndrome (SM). The prevalence of metabolic syndrome in different countries of the world differs in Europe by about $15 \%$, in South Korea about $14.2 \%$, and in the Americas by $24 \%$ [3].

Indonesia is one of the countries that has a high prevalence value in metabolic syndrome (SM). The influence of globalization is one result of the incidence of metabolic syndrome (SM) especially in terms of consuming food from what was originally traditional to Westernized and instant. Research conducted by Lutsey et al., concluded that foods such as processed meat and fried foods can trigger an increase in metabolic syndrome (SM) [4]. While the study conducted by Suhaema \& Herta (2015) on Indonesians got a prevalence result of $23 \%$, consisting of women by $26.6 \%$ and men by $18.3 \%$. The habit of consuming salty foods is one of the triggers of increased metabolic syndrome in Indonesian society [5]. To minimize the risk of metabolic syndrome it is necessary to improve a healthy lifestyle and be selective towards food. One way is the consumption of diverse foods or diversification of food. The main staple food in Indonesia is rice. Indonesian people's dependence on rice is considered able to endanger food security. The amount of rice consumption in 2011 reached an average of 139 $\mathrm{kg}$ per capita, which if it is not immediately followed up it will further weaken food security in Indonesia. The source of carbohydrates is not only from morning rice, but there are still many other sources of carbohydrates, one of which is the type of tubers such as suweg and 
ganyong, the yam can be processed into a product that is able to maintain food security in Indonesia called analog rice.

Analog rice is artificial rice made from non-rice foodstuffs that are usually made from tubers and grains that include sweet potatoes, kimpul, and corn. This food diversification program in addition to being an alternative to reduce the prevalence value of metabolic syndrome, this program can also be used as an alternative to increase the food value of people in Indonesia, especially in the form of tubers and grains other than rice. Ganyong tubers(Canna edulis)are one of the herbs clustered and included in the tubers [6]. The nutritional content in analog rice made from ganyong tubers includes carbohydrates obtained from dry weights that range from about $\pm 96.49 \%$, The protein content of resistant starch ganyong tubers is higher which is about $0.56 \%$ compared to pure ganyong starch about $0.38 \%$, the fat content in resistant starch flour is $0.28 \%$ while for pure ganyong starch $0.16 \%$, the water content in ganyong tuber resistant starch is about $9.38 \%$ while in pure ganyong starch is $15.19 \%$ this is due to the high amylose content, then the ash content in resistant starch is $0.68 \%$ while in pure ganyong flour is $0.56 \%$ [6]. In kimpul bulbs, their nutritional content is influenced by variety, harvest age, soil fertility, and climate [7]. While in corn has a high enough protein content of $9.2 \%$ [8], which is higher protein content than rice rice $6.78-7.92 \%$ [9].

\section{MATERIAL AND METHOD}

Tools using to produced of analog rice are dryer oven, noodle maker, and others. Meanwhile the ingredients are including suweg flour, ganyong flour, mocaf, coconut oil, and gelatine.

The process of making flour begins by peeling the bulbs, then washed and sliced using a thin bulb slicer, then for the sliced bulbs are soaked so that the attached sap is lost after it is washed back until clean. The bulb slices are dried using a $70^{\circ} \mathrm{C}$ oven for 12 hours, then if they are dry weigh each weight and mashed using a blender. Then filtered using mesh sying and lastly weighed each weight of the flour bulbs.

The process of making analog rice from various types of tubers begins with the manufacture of flour. All the ingredients are mixed up and extrude with a noodle maker. The next step is drying the rice analog at $60^{\circ}$ Celcius for 60 minutes.

\section{RESULTS}

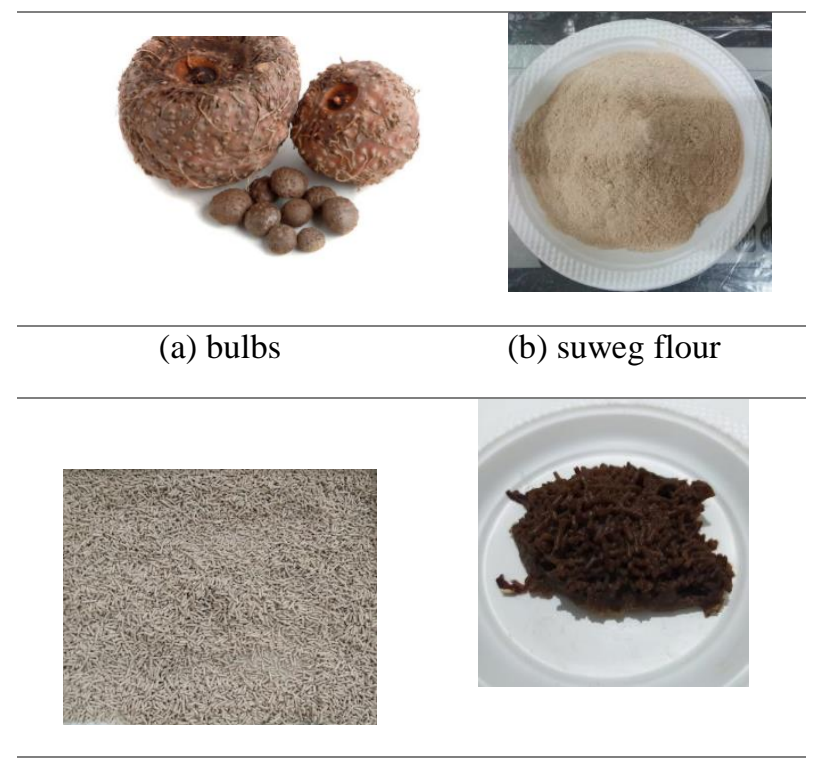

(c) raw analog rice

(d) cooked analog rice

Figure 1. The results of making analog rice derived from suweg tubers are as follows

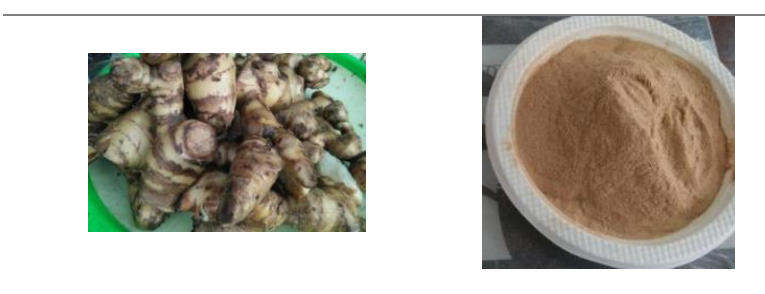

(a) bulbs

(b) flour

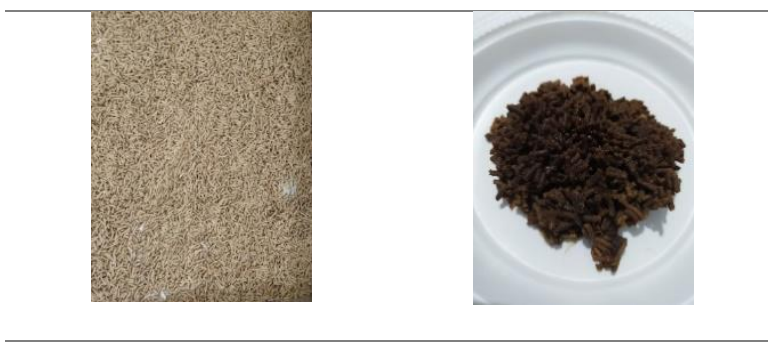

(c) raw analog rice

(d) cooked analog rice

Figure 2. The results of making analog rice derived from ganyong tubers are as follows

The results of examining water and ash content on suweg bulbs were $7.41 \%$ and $2.63 \%$, respectively. Compared with the research results conducted by Richana \& Sunarti (2004), the content of water content obtained is more significant than $9.4 \%$ and ash levels are also more at $3.81 \%$ [6]. While in ganyong tubers, the moisture and ash content is $8.08 \%$ and $3.34 \%$, respectively (Table 1). 
Table 1. Water and ash content on the 100 grams

\begin{tabular}{|l|l|l|}
\hline \multicolumn{1}{|c|}{ Variable } & \multicolumn{1}{|c|}{ Suweg (\%) } & $\begin{array}{c}\text { Ganyong } \\
(\%)\end{array}$ \\
\hline Water & 7,41 & 8,08 \\
\hline Ash & 2,63 & 3,34 \\
\hline
\end{tabular}

In 100 grams of suweg tuber samples containing nutrients including energy: $373 \mathrm{kcal}$; Protein: $3.08 \%$; Fat: $2.69 \%$; and carbohydrates: $84.19 \%$. Compared to research conducted by Richana \& Sunarti (2004), results include carbohydrates: $80-85 \%$; protein: $5.22 \%$; fat: $0.81 \%$ [6]. While in 100 grams of ganyong tuber samples contain nutrients including Energy: $367 \mathrm{kcal}$; protein: 2.68\%; fat: $2.53 \%$; carbohydrates: $83.37 \%$ (Table 2).

Table 2. The macronutrient analysis of tuber nutrients in 100 grams of samples.

\begin{tabular}{|l|l|l|}
\hline \multicolumn{1}{|c|}{ Variable } & \multicolumn{1}{c|}{ Suweg } & Ganyong \\
\hline Energy (kcal) & 373 & 367 \\
\hline Protein (\%) & 3,08 & 2,68 \\
\hline Fat $(\%)$ & 2,69 & 2,53 \\
\hline Carbohydrates $(\%)$ & 84,19 & 83,37 \\
\hline
\end{tabular}

Based on the results of calculations of the percentage of RDA on the diet of $2150 \mathrm{kcal}$, the exact number results in suweg, namely protein $122.55 \mathrm{~g}$, fat $80.41 \mathrm{~g}$, carbohydrates 562,225 g, calcium 184, 685 g, sodium $2,365 \mathrm{~g}$, and iron by $661.99 \mathrm{~g}$. while in ganyong obtained the exact figure of protein of $106.64 \mathrm{~g}$, fat $75.5 \mathrm{~g}$, carbohydrates $555.99 \mathrm{~g}$, calcium $77.83 \mathrm{~g}$, sodium 3,655 $\mathrm{g}$, and iron by $65,575 \mathrm{~g}$ (Table 3 ).

Table 3. The percentage based on AKG diet 2150

\begin{tabular}{|l|l|l|}
\hline \multicolumn{1}{|c|}{ Variable } & \multicolumn{1}{|c|}{$\begin{array}{c}\text { Suweg } \\
(\%)\end{array}$} & \multicolumn{1}{|c|}{$\begin{array}{c}\text { Ganyong } \\
(\%)\end{array}$} \\
\hline Protein & 5,7 & 4,96 \\
\hline Fat & 3,74 & 3,51 \\
\hline Carbohydrates & 26,15 & 25,89 \\
\hline Calcium & 8,59 & 3,62 \\
\hline Sodium & 0,11 & 0,17 \\
\hline Iron & 30,79 & 30,5 \\
\hline
\end{tabular}

Carbohydrate composition in 100 grams sample of suweg bulbs include starch: $52.02 \%$; amylose: $17.86 \%$; coarse fiber: 3\%; total sugar $23.3 \%$; Reduced sugar: $3.21 \%$; calcium $60.16 \%$; Sodium: $2.69 \%$; Iron: $8.93 \%$; Antiosidan: $481.62 \%$. When compared with the results of the study Rochmah et al., (2019) and Septiani et al., (2015) obtained results of $24.5 \%$ amylose; $88.50 \%$ starch; $3.55 \%$ reduced sugar; $9.53 \%$ total sugar; and $13.58 \%$ coarse fiber[8],[9]. Then according to data table of Indonesian Food Composition 2017 by the Director General of Public Health (2018) suweg has a calcium content of $3.82 \%$; sodium $0.47 \%$; and zinc $0.77 \%$. While the composition of carbohydrates in 100 grams of ganyong tuber samples include $48.23 \%$ starch; $22.84 \%$ amylose; $2.86 \%$ coarse fiber; $19.5 \%$ total sugar; 4.12 reduced sugar; $25.34 \%$ calcium; $4.16 \%$ sodium; $8.85 \%$ iron; $207.97 \%$ antioxidants (Table 4).

Table 4. Carbohydrate compound and micronutrient in 100 grams of sample

\begin{tabular}{|l|l|l|}
\hline Code & Suweg & Ganyong \\
\hline Starch (\%) & 52,02 & 48,23 \\
\hline Amylose (\%) & 17,86 & 22,84 \\
\hline Crude fiber (\%) & 3 & 2,86 \\
\hline Total sugar (\%) & 23,3 & 19,5 \\
\hline Reduced sugar (\%) & 3,21 & 4,12 \\
\hline Calcium (\%) & 60,16 & 25,34 \\
\hline Sodium (\%) & 2,69 & 4,16 \\
\hline Iron (\%) & 8,93 & 8,85 \\
\hline Antioxydant (\%) & 481,62 & 207,97 \\
\hline
\end{tabular}

\section{DISCUSSION}

Suweg is a tuber that is very abundant, especially in Southeast Sulawesi. Besides that suweg tubers are still not widely known related to their potential and application by the community. The advantages of this suweg bulb are having high carbohydrates $(83.7 \%)$, lowfat content $(0.7 \%)$. With this content, suweg tubers are suitable for use as food with high energy sources. Suweg can also be used as an alternative to increasing food diversification by utilizing local tubers. Suweg bulbs have a low glycemic index value. It can be developed as an alternative foodstuff, one of which is as an analog ricemaking material. The nutritional content possessed by suweg bulbs, especially after being used as in the form of flour, is carbohydrate content between $80-85 \%$ in wet weight, protein content in suweg flour is $5.22 \%$, fat content is $0.81 \%$, water content is $9.4 \%$, and ash content is around $3.81 \%$ [6]

Suweg bulbs have an amylose content of $24.5 \%$; starch $88.50 \%$; sugar reduction of $3.55 \%$; total sugar 9.53\%; coarse fiber $13.58 \%$ [6],[8]. The glycemic index suweg, according to research conducted by Nurdyansah et al. (2019), is less than 55 included in low IG. Suweg bulbs are also anti-inflammatory, anti-venom, relieve bleeding, and treat wounds because they contain several antioxidant compounds such as flavonoids. In addition, there are other phytochemical compounds in the form of alkaloids, polyphenols, saponins, and tannins. The results are based on Firman et al. (2016) research that tested antioxidant activity on suweg bulbs with three different types of solvents. Based on data in the Indonesian Food Composition Table 2017 by the Director-General of Public Health (2018), fresh suweg has a $\beta$-carotene content of $24 \mathrm{mcg}$, vitamin $\mathrm{C}$ of $2.22 \%$ or equivalent to 2 $\mathrm{mg}$, calcium $3.82 \%$ or equivalent to $42 \mathrm{mg}$, iron $5.91 \%$, potassium $8.51 \%$, sodium $0.47 \%$, and zinc by $0.77 \%$.

Ganyong tubers (Canna edulis) are one of the herbs clustered and included in the tubers. Ganyong tubers can be used as one of the functional food ingredients in Indonesia. The content in ganyong tubers includes 
carbohydrates that are higher than other bulbs to be consumed as energy providers for the body [7]. The nutritional content in analog rice made from ganyong tubers includes (1) carbohydrates obtained from dry weights that range from about $\pm 96.49 \%$, (2) the protein content of ganyong tuber resistant starch is higher, which is about $0.56 \%$, compared to pure ganyong starch about $0.38 \%$, (3) the fat content in resistant starch flour is $0.28 \%$ while for pure ganyong starch $0.16 \%$, (4) the water content in ganyong tuber resistant starch is about $9.38 \%$ while in pure ganyong starch $15.19 \%$ this is due to the high amylose content, (5) the ash content in resistant starch is $0.68 \%$ while in pure ganyong flour is $0.56 \%[7]$

The age of the bulb harvest influences the content of coarse fiber in flour. The older the bulbs used, the fewer starch levels in the bulbs, and there is a change from starch to fiber. This dietary fiber affects blood glucose levels. These fibers can inhibit physical digestion and enzyme activity, which causes slow digestion of starch and lower blood glucose response [7]. Ganyong tuber flour has a higher amylopectin content of $50.90 \%$ compared to amylose content of $42.49 \%$. The higher amylopectin content will affect the texture of analog rice after cooking [11]. Ganyong bulbs contain carbohydrates in complex sugars and secondary metabolic substances such as alkaloids, flavonoids, steroids, andphenolics [12]. Ganyong tubers have a relatively high nutritional value and can be processed into flour or starch. The nutritional composition of ganyong bulbs in $100 \mathrm{~g}$ is carbohydrates $22.60 \mathrm{~g}$, calcium $21.00 \mathrm{mg}$, protein $1.00 \mathrm{~g}$, iron $1.90 \mathrm{~g}$, phosphorus $70.00 \mathrm{mg}$, vitamin B1 $0.10 \mathrm{mg}$, vitamin C $10.00 \mathrm{mg}$ and water $70 \mathrm{~g}$ [13].

As for corn analog rice which is a pioneer analog rice is as follows. According to the other study, corn analog rice has a protein percentage of $7.19 \%$, the water content of $6.3-9.32 \%$, the fat content of $4.1 \%$, carbohydrates of $90.06-92.41 \%$, the amount of carbohydrates in corn analog rice is highly rated because it is composed of starches of (70-80\%) [14][15]. Based on the literature found, the best corn analog rice formulation with a recipe of $70 \%$ cornstarch: $30 \%$ red bean flour and addition of $1.5 \%$ powder have a carbohydrate content of $78.95 \%$, the protein content of $13.44 \%$, fat content of $0.94 \%$, water content of $5.15 \%$, rehydration coefficient of 3.73 and Kamba density of $0.517 \mathrm{~g} / \mathrm{ml}$. IR 64 rice is superior to the aroma, flavor, and color aspects, but panelists' fondness for IR64 rice and analog rice is no different. This analog rice already meets the SNI standard of rice when viewed from its moisture content [16].

\section{CONCLUSION}

The results of this study are the energy almost are as many ganyong as suweg. In addition, the content of protein, fat, and carbohydrate is suweg larger than ganyong. Furthermore, the starch and total sugar are fewer in ganyong than suweg. The other carbohydrate compound is amylose, and reduced sugar is bigger ganyong than suweg.

\section{AUTHORS' CONTRIBUTIONS}

YR, AG, RM: concept and design, data analysis, writing the manuscript, NIK, INF: data collection, visualize data.

\section{ACKNOWLEDGMENTS}

The authors would like to thank Universitas Negeri Malang that supported this study.

\section{REFERENCES}

[1] K. Li, R. Yin, Y. Wang, and D. Zhao, "Associations between exposure to polycyclic aromatic hydrocarbons and metabolic syndrome in U.S. adolescents: Cross-sectional results from the National Health and Nutrition Examination Survey (2003-2016) data," Elsevier Inc, Jul. 2021, doi:

https://doi.org/10.1016/j.envres.2021.111747.

[2] Lasmadasari N. and M. U. Pardosi, "Study of prevalence and risk factors of metabolic syndrome in fishermen in Malabro Bengkulu Village," J. MKMI,vol. 12, no. 2, pp. 98-103, Jun. 2016.

[3] S. Driyah, R. Oemiati, Rustika, and N. S. Hartati, "Predictor of Syndrome Metabolic: Prospective Cohort Study for Six Years in Bogor, Indonesia. R\&D Media, vol. 29, no. 3, pp. 215-224, Sep. 2019 , doi: https://doi.org/10.22435/mpk.v29i3.654.

[4] P. Lutsey, L. Steffen, and J. Stevens, "Dietary intake and the development of the metabolic syndrome: The atherosclerosis risk in communities study," Circ. Ser. Internet, vol. 117, no. $6, \quad$ doi: http://circ.ahajournals.org/cgi/doi/10.1161/CIRC ULATIONA_HA.107.71.

[5] Suhaema and H. Masthalina, "Consumption Patterns with Metabolic Syndrome in Indonesia," J. Kesehat. Masy. Nas. , vol. 9, no. 4, pp. 340-347, May 2015.

[6] N. Richana and T.C. Sunarti, "Characterization of the Physical Phytochemical Properties of Tuber flour and Starch Flour from Ganyong, Suweg, Ubikelapa and Gembili Bulbs," J. Pasca panen,vol. 1, no. 1, 2004.

[7] V. D. Putri and F. Dyna, "Standardization of Ganyong (Canna edulis ker) As An Alternative 
Food of Diabetes Mellitus Patients," J. Catalyst,vol. 4, no. 2, pp. 111-118, 2019.

[8] M.M. Rochmah, M. K. Ferdyansyah, F. Nurdyansyah, and R.M. D. Testi, "Effect of the addition of hydrooloids and sucrose concentrations on physical and organoleptic characteristics of papaya sheet jam (Carica Papaya L.)," J. Food and Agroindustry,vol. 7, no. 4, pp. 42-52, October 2019.

[9] D. Septiani, Y. Hendrawan, and R. Yulianingsih, "Test the physical, chemical, and organoleptic characteristics og suweg tuber flour (Amorphophalluscampanulatus B) as an alternative food ingredient," J. Bioprocess Komod. Trop., vol. 3, no. 1, 2015.

[10] Amelda, Ansharullah, and R. H. F. Faradila, "Effect of Suweg Flour Combination (Amorphophallus paeoniifolius) and Seacress Flour (Ulva Lactuca) On Organoleptic and Physicalochemical Characteristics of Wet Noodles," J. Science and Teknol. Food,vol. 5, no. $5,2020$.

[11] S. Salsabila, A. Hintono, and B. E. Setiani, "Effect of The Addition of Red Bean Flour On the Chemical and Hedonic Properties of Analog Rice Made from Ganyong Tubers (Cannaedulis Ker.)," J. Agrotek Ummat,vol. 7, no. 2, 2020.

[12] N. Noriko and A. Pmbudi, "Food Diversification Of Carbohydrate Source Canna edulis Kerr. (Ganyong)," J. Al-Azhar Indones. Science and Technol Series. , vol. 2, no. 4, 2014.

[13] D. R. Budiarsih, B. K. Anandito, and G. Fauza, "Study of The Use of Ganyong Flour (Canna Edulis Kerr) as a Substitute for Wheat Flour in the Manufacture of Dry Noodles," J. Teknol. Tenderloin. Patch. , vol. 3, no. 2, 2010.

[14] H. Agu and A. Michael-Agwuoke, "Optimization of Soaking Duration and Temperature for Two Nigerian Rice Cultivars," Niger Food J,vol. 30, no. 2, pp. 22-27, 2012.

[15] S. Noviasari, F. Kusnandar, and S. Budijanto, "Development of Analog Rice By Utilizing White Corn," J Teknol And Ind Pangan,vol. 24, no. 2, pp. 194-200, 2013.

[16] Y. J, P. Santos, and O. Campanella, "A Study to characterize the mechanical behavior of semisolid viscoelastic systems under compression chewing case study of agar gel," J Texture Stud, vol. 43, no. 6, pp. 459-467, 2012. 